\title{
Petty commodities, serious business: The governance of fashion jewelry chains between China and Ghana
}

In many parts of the world, people access consumer goods mainly via informal economic networks. This article analyzes the governance of petty commodity chains through a case study of Chinese fashion jewelry produced for the Ghanaian market. "Petty commodity chains", denotes a particular type of global value chain, where production, trade, and distribution are carried out by small, unregistered businesses, between which personalized relationships and informal infrastructure enable transactions. These chains neither are controlled by lead firms at the production or distribution ends, nor are they made up of pure market linkages. Weak formal institutions and an intensely competitive commercial environment encourage business actors to establish enduring relationships. Credit relations run through long stretches of the chain and create mutual dependencies. The concept of "beholden value chains" is introduced to describe the co-dependency between business actors and the coordination of activities in petty commodity chains.

\section{Introduction}

The China-made jewelry sold in Ghana is not made to last. Produced from cheap base metals, glass, plastic, and synthetic stones, it is worn for a few months until it breaks or goes out of style. The retail price of a new pair of earrings can be as low as one Ghanaian cedi (US\$0.26). Yet, cheap jewelry is big business. Thousands of Chinese producers sell to African markets. In Ghana alone, dozens of traders import more than a ton of jewelry each per year. Jewelry vendors are ubiquitous in urban areas. Most female guests at the elaborate weddings and naming ceremonies in the capital of Accra wear Chinese jewelry. This article draws upon an ethnographic study of China-Ghana fashion jewelry export to elucidate how petty commodity chains are governed. The analysis adopts a global value chain (GVC) approach, and aims to bring informality and South-South economic linkages further into the purview of GVC research.

"Petty commodity chains" denotes the production, trade, and distribution by small, unregistered businesses, between which personal relations and informal infrastructure enable transactions. The concept relates to Marx's distinction between capitalist commodities and simple commodities, where the latter category comprises producers who own the means of production and put in the required labor themselves (1991, orig. 1867-1894). Petty capitalism has always existed alongside other modes of production, and articulates with the wider political-economic systems it is part of (Smart and Smart 2006). Petty capitalist businesses are 
defined by their small size, low-technology intensiveness, and the labor put in by the owner. Owners may employ a few workers, whether blood kin, adopted kin, apprentices, or wage laborers (Gates 1996, Smart and Smart 2006). Improved transportation and communication technologies enable small firms to operate on a global scale. The cumulative impact of these businesses on regional economies and global trade flows is immense, and they tie together the fortunes of distant places.

GVC analysis provides insight into how economic actors create and capture value by taking advantage of geographic differences in costs, factor endowments, regulatory frameworks, and consumer bases. The notion of global production networks (GPNs) was introduced as a critique of the purportedly narrow focus of GVC analysis, and places business actors and their position in multi-sited networks center stage (Coe and Yeung 2015). The GVC and GPN literatures have converged over time, and concepts and analytical insights span the two strands. This article draws upon literature from both traditions, but employs the terminology and methodology of the GVC approach.

The organization of petty commodity chains fits poorly with the prevailing models of GVC and GPN governance, which promote the idea that the chains/networks are headed by lead firms with power and organizational capacity to exercise market control (Coe and Yeung 2015:40). The China-Ghana jewelry chain is not controlled by lead firms, yet relationships between actors along the chain are not market-based. Economic interaction between vertically related businesses displays relative stability. Although power is not concentrated at a few spots along the value chain, relationships are characterized by transactional dependency. Based on the literature review and the empirical case, this study proposes that the governance of petty commodity chains can be captured by the concept of beholden value chains.

The following section reviews the literature on global value chains and informal transborder trade, and briefly describes how economic relations between China and Ghana have developed. Next, I outline the methodological approach employed to obtain data on economic relations in contexts of high informality and sometimes illegality. The subsequent analysis of the governance of petty commodity chains is organized into three parts. First, I analyze the structure of the China-Ghana jewelry chain, from manufacturers to retailers. The second part focuses on credit relations, which I suggest promote enduring transactional relationships along the value chain. The third part introduces the governance type of beholden value chains. The conclusion calls for research that analyzes not only the configuration of petty commodity chains, but also their wider consequences for economic development. 


\section{The governance of petty commodity chains}

This article will build on insights from two research traditions: the GVC and GPN approaches and ethnographic studies of informal transborder trade. Both traditions move beyond simple input-output analysis of economic transactions and emphasize the roles of power relations and institutions. The former tradition is marked by a strong commitment to theory-building and to the abstraction of value chain characteristics, and focuses mainly on the formal economy (Phillips 2011). The latter tradition, ethnographic studies, places greater emphasis on informal economic activities, and approaches informality and formality as a structural blending rather than as discrete spheres. Informal modes of organization play a role in all forms of production, but are particularly pervasive in petty capitalist businesses.

\section{Global value chains}

GVCs refer to the internationally dispersed activities throughout a product's lifespan, from conception through production, marketing, retail, consumption, and disposal or recycling. GVC and GPN research constitutes a key tradition within economic geography. However, the spatial dynamics of the diverse economies in the global South are often neglected by economic geographers, and the sub-discipline could derive further synergies from broadening its geographic focus (Murphy 2008, Economic Geography 2011). Furthermore, informality arguably ought to be better incorporated into GVC and GPN research, both as an empirical area of enquiry and in theorizing (Phillips 2011). For example, Coe and Yeung's (2015) recent book advancing GPN research mentions informal regulation and knowledge only in passing, and does not consider the difference informality makes.

The studies that examine how informality shapes GVCs and GPNs have generated some important insights. Horner's study of Indian pharmaceutical firms exporting generic drugs to semi-regulated markets in developing countries suggests that "strategic decoupling" with ensuing recoupling is an alternative to GPN intergration as a route to economic development (Horner 2013). Informal ties to the state can be an important means to gain global market access, as in the case of Vietnamese clothing producers (Thomsen 2007). Informal labor intermediaries have become influential in shaping GPNs, and some states have actively accommodated these intermediaries (Barrientos 2013, Mezzadri 2010). Analyses of industrial upgrading in developing countries raise the question of whether the articulation of informal producers into GPNs has positive or impoverishing effects (Nadvi 2004, Murphy 2007). 
On the distribution end, African trade networks have proved instrumental in connecting Asian producers to African markets (Prag 2013). While established West African traders resisted the incorporation of Chinese manufacturers into local networks, incipient traders have liaised with Chinese producers to circumvent prevailing economic hierarchies (Axelsson and Sylvanus 2010). The hybrid character of the state and the processual nature of state-society relationships were highlighted in Brooks' research on GPNs for used goods sold in Mozambique: Importers of second-hand clothing and cars from Asia negotiated formal and unofficial charges, whereas dense informal structures disadvantaged transnational companies (Brooks 2012, 2015). Research on China-Africa trade has pointed out that these value chains incorporate a large number of small-scale actors, none of whom individually controls the chain (Lyons et al. 2013).

Global economic trends have made it imperative not to take the formal economy as a self-evident theoretical and empirical starting point in GVC analysis. End markets for global value chains are shifting away from Europe and North America, which will influence the governance structures of both GVCs and global capitalism (Gereffi 2014). The share of world trade between developing countries doubled between 2000 and 2013, with a corresponding decrease in North-North trade (UN Comtrade 2015). These shifts imply that economic informality becomes more important: The size of the informal sector is negatively correlated with a country's wealth, and is smallest in high-income OECD countries and largest in SubSaharan Africa (Schneider et al. 2010).

China is now Africa's largest trading partner. Research on value chains between China and Sub-Saharan Africa highlights that Chinese consumers demand cheap, undifferentiated commodities and hold suppliers to low environmental and social standards. Without consumer-driven industry standards, businesses arguably engage in price-based competition that often proves immiserizing for workers, firms, and countries (Kaplinsky 1998, Kaplinsky et al. 2011). Other studies paint a less dismal picture, and suggest that the growing middle class in developing countries will alter the definition of corporate social responsibility rather than reduce its importance (Guarín and Knorringa 2013, Nadvi 2014). A review of SouthSouth value chain research suggests that such value chains are more accessible due to lower quality-, social-, and environmental standards, but also prone to intense price-based competition (Horner 2015).

The topic of governance is central to GVC research. Studies of global commodity chains, the predecessor of the GVC perspective, highlight the difference between producerdriven and buyer-driven chains. The former are typically found in technology-intensive 
industries, where producers are lead firms; the latter are characteristic of labor-intensive industries, where lead firms are merchandisers who control market access (Gereffi 1994). More detailed typologies have subsequently been developed, in which the complexity of transactions, possibilities for codifying knowledge, and suppliers' capabilities determine how lead firms exert their power (Gereffi et al. 2005, Sturgeon 2002, Humphrey and Schmitz 2002). Studies of manufacturing industries with end markets in the global North constitute the empirical underpinning of these typologies. Research from developing country contexts criticizes these frameworks for focusing excessively on lead firms, thus diverting attention from alternative paths to market integration and regional development (Horner 2013, Murphy and Schindler 2011). Drawing upon postcolonial theory, an analysis of the GPN for wildflowers in South Africa's Western Cape purports that a strong focus on the entity of the firm in GVC/GPN research precludes richer accounts of how economic processes are historically grounded and contextually conditioned (Hughes et al. 2015).

Credit mechanisms play a prime role in structuring GVCs. The 2008 financial crisis eroded trust between international banking counterparts and intensified exchange-rate risks, resulting in reduced trade credit (Cattaneo et al. 2010). When lead firms in buyer-driven chains are denied credit, the effects transmit directly to manufacturers (Milberg and Winkler 2010). The termination of loans available to single firms thus reverberated throughout GVCs (Escaith and Gonguet 2009).

\section{Studies of informal transborder trade}

Numerous ethnographic studies from the early 1990s onwards explored how people carve out a living through informal transborder trade. The scholarship commits to understanding transnational economies from the perspectives of the people engaging in them. Whereas GVC and GPN research tends to focus on successful economic integration (Bair and Werner 2011), research on informal transborder trade takes rupture as its starting point. Informal trade was a common response to the "uncertain transitions" (Burawoy and Verdery 1999) produced by the collapse of Soviet-bloc regimes (Konstantinov et al. 1998) and the structural adjustment programs implemented across Africa (Meagher 2003). The disruptions depleted livelihoods and forced people to look for new sources of revenue, while simultaneously expanding opportunities for transborder trade.

The problem of governance is central to the literature on informal trade. Traders are vulnerable to opportunism because transactions are unprotected by formal justice systems. Problems along the value chain may also start with traders who default, for example due to 
market plunges, confiscations in customs, and fashion misjudgments (Yükseker 2007). The literature on Chinese business networks has highlighted the role of kinship relations in creating dependable governance structures within volatile political environments (Yeung 2004). Ethnographic studies from other contexts demonstrate the downside of personal relationships in business: The advantages of knowing somebody personally - through kinship, friendship, or romantic relationships - must be weighed against the social obligations that come with such bonds (Rubbers 2009). Common adherence to non-state institutions, such as religious societies, is an alternative way of sustaining reciprocal relationships and generating enforceable trust (Ebin 1993).

Informal and formal institutions interlink in multiple ways to advance and regulate petty trade. First, employment in the formal sector provides traders with access to resources such as buyer networks, discounted plane tickets, and capital (MacGaffey and BazenguissaGanga 2000). Second, exclusion from formal-sector employment pushes people towards the informal economy, where transborder trade is an accessible option (Morawska 1999). Third, traders often pay a mixture of official customs fees and bribes when they import goods, and the separation between formal and informal institutions may seem irrelevant from their perspective (Peberdy 2000). Finally, rather than suppressing the trade in illegal goods, states may act as distributors of rents (Meagher 2003).

Credit relations represent a central topic in research on informal trade. Small-scale traders, with limited capital and few prospects of accessing formal lending institutions, depend on suppliers to sell goods on credit. A case in point is the trade in Mexican chilies and mangos to the United States, where business success hinges on middlemen who provide "the float" (la maroma) of money in acquisitions and dispositions (Alvarez 2005). Lagged payments represent a mechanism through which buyers and sellers share risk, as explained in a study of the shuttle trade in garments from Istanbul to the Former Soviet Union: Turkish suppliers allowed cash-strapped traders to pay for the goods upon selling them back home, knowing that the money was lost if the trader ran into trouble. Credit-granting practices arose from interdependencies between market actors rather than shared moral principles: Merchants had to grant credit in order to get customers, while traders depended on delayed payments to run their businesses (Yükseker 2007). In West Africa, lending to itinerant traders has a long history: Female traders had lines of credit amounting to thousands of pounds sterling with overseas firms in colonial times (Galletti et al. 1956). In all the above-mentioned cases, credit structured the relations between several businesses along the value chain. 


\section{China-Ghana economic interaction}

The year-on-year growth in officially recorded exports from China to Ghana after the turn of the millennium has been almost 30 percent. China reported US\$5.313 billion worth of exports to Ghana in 2015 (UN Comtrade 2015). Ghana is the eighth-largest recipient of Chinese loans to African governments (Brautigam 2016).

Any discussion of Africa's international trade must include caveats concerning data quality (Gibbon and Ponte 2005). The China-Ghana jewelry trade is no exception. Official statistics reflect under- and misreporting at the points of export and import. In 2013, Chinese customs stated that 412 tons of jewelry, on average worth US\$4.8 per kilo, were exported to Ghana; Ghanaian customs recorded 1,364 tons of jewelry imports valued at US\$0.9 per kilo from China (UN Comtrade 2015). One reason for the discrepancy is that the jewelry often is shipped as personal luggage from China, and registered only by Ghanaian customs. Low value estimates are advantageous for customs clearance purposes. The valuation is negotiated at the point of importation, commonly by professional clearing agents hired by the traders.

\section{Methodology}

The analysis draws upon 16 months of ethnographic fieldwork between 2009 and 2016 in Guangzhou, South China, as well as shorter data collection periods in Makola market, Ghana, along the Nigerian section of the trans-West African highway, and in Lomé, Togo. Togo serves as a point of importation for some of the jewelry sold in Ghana today, whereas Ghanaian wholesalers previously traveled to Nigeria to buy jewelry manufactured in Asia. I negotiated access to actors along the jewelry chain through Chinese suppliers, who were positioned in the middle of the value chain and had contacts with both upstream and downstream actors. In 2015, I followed two suppliers to Ghana to observe their debtcollection methods, interview wholesalers and retailers, and study how consumers used the jewelry.

Access and trust-building were main challenges during the fieldwork, as business competition was tough and legal transgressions were common. Trust-building was made easier by the fact that as a white European, I was unlikely to be a competitor. African traders identified me as a fellow foreigner in China. Speaking Mandarin helped me establish rapport with Chinese informants and collect observational data. The mobile nature of business operations was addressed by following select research informants and goods in various geographic locations (see Marcus 1995 for a discussion of the method of following). By observing businesses and people over time, I could capture how their successes and failures 
were influenced by macro-level trends (e.g. exchange-rate fluctuations) as well as by idiosyncratic events (e.g. theft).

The intersections between economy and culture produce a continuum of different lifeways in post-colonial contexts (Zein-Elabdin 2011). These can be studied from the perspectives of the participants through ethnographic methods. Economic ethnographies describe how actors navigate profit-oriented and moral economies, though such ethnographies do not claim that economies and cultures are ontologically separate (see Pollard et al. 2011). My approach was inspired by global ethnography, which applies an ethnographic microscope to enrich theories about global processes from the ground up (Burawoy and Verdery 1999).

\section{The structure of the China-Ghana jewelry chain}

The analysis of governance in the China-Ghana jewelry chain will be presented in three parts. The current section provides an overview of the actors operating along the chain and the markups at each stage. The situation superficially resembles one of market governance: There are many economic actors at every stage in the value chain, entry barriers are low, and profit margins are narrow. Yet, the relationships along the chain are relatively stable and characterized by repeat transactions between vertically related businesses. The next section explains the permanence of transactional relationships by providing examples of symbolic exchanges between business actors and by describing credit relations along the value chain. Businesses with little capital depend on receiving credit from upstream partners in order to reach profitable volumes. Conversely, businesses grant credit downstream to retain customers and increase turnover. The resulting mode of governance - beholden value chains - is described in the final part of the analysis.

Figure 1 gives an overview of the prices at different stages of the value chain of one jewelry model - heart-shaped earrings. The jewelry chain contains four main steps prior to consumption. First, Chinese manufacturers carry out one or more production procedures in the functionally disintegrated manufacturing of the jewelry. Second, suppliers in China take orders from traders, identify manufacturers for each process, and coordinate the production. Third, Ghanaian traders travel to China to purchase goods wholesale from suppliers, and resell the jewelry to retailers. Finally, Ghanaian retailers market the jewelry to end customers. 


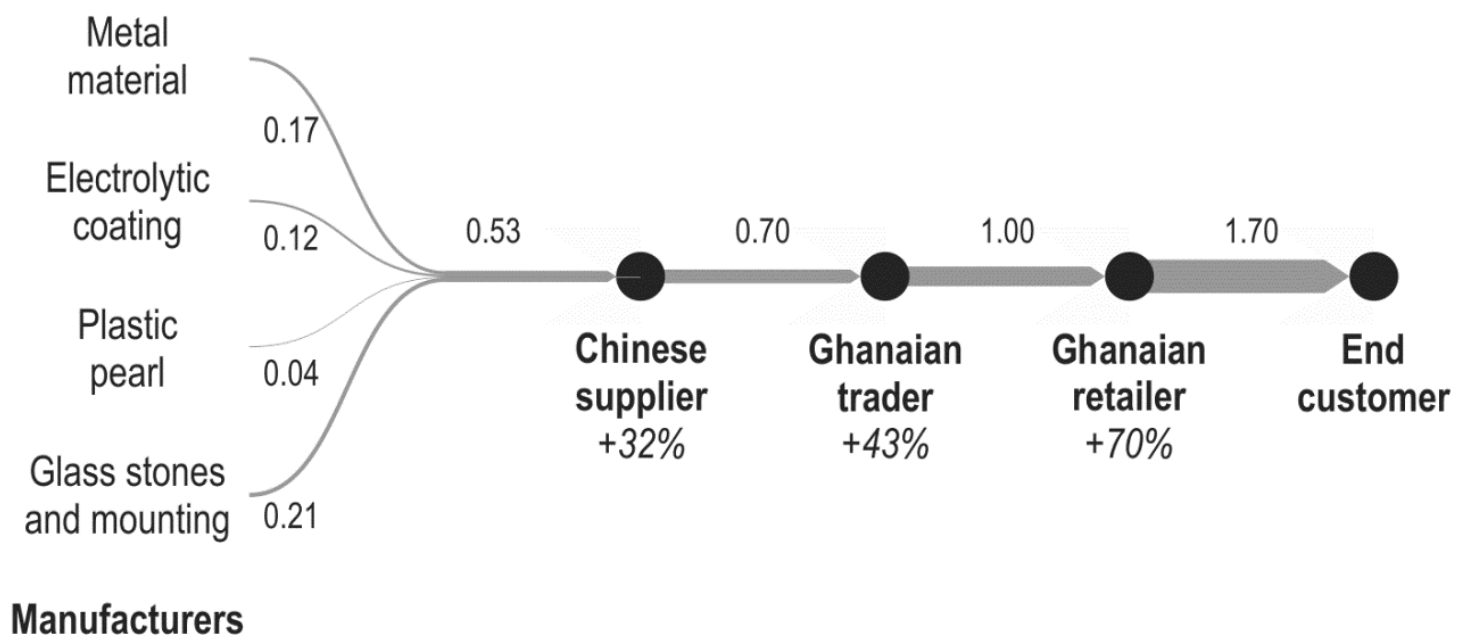

Figure 1. Price of earrings with pink plastic pearls at each stage of the value chain. All prices in RMB per pair.

Source: Author's fieldwork 2014-15. Exchange rates: RMB/GHS 1.7, US\$/RMB 6.2.

The customary retail price of low-grade fashion earrings sold on the streets of Accra was one Ghanaian cedi (GHS) per pair (CNY1.7) at the time of fieldwork. The retailers paid traders GHS3.5 for six pairs of these earrings. At these prices, the retailers were hard-pressed to sell enough to cover their transportation and food costs, except during holiday seasons when sales surged. Due to the fixed prices at the wholesale and retail stages, the profits retained by traders, suppliers, and manufacturers were largely dictated by the production costs of different models.

\section{Chinese manufacturers}

The Chinese jewelry destined for African markets is almost exclusively produced in the provinces of Guangdong and Zhejiang, which spearheaded the emergence of export-oriented manufacturing in China. They have a large base of informal, small-scale, and flexible manufacturers that produce for both developed- and developing-country markets. Following Deng Xiaoping's reform policies, Hong Kong investors established small-scale enterprises in Guangdong through negotiation with local authorities, often in sites where they had social connections. Gift exchange between petty capitalists and local authorities helped bridge capitalist and socialist economies (Smart and Smart 1991). Zhejiang followed a different economic trajectory, in which the early growth in manufacturing was dominated by indigenous family-owned businesses protected by local government officials (Wei et al. 2007). The limits to growth in labor-intensive manufacturing are now increasingly apparent in China. The Guangdong provincial government is therefore attempting to "empty the cage and change 
the birds," that is, to upgrade to high-end manufacturing, service provision, and research (Liao and Chan 2011). However, the policy has so far not affected low-end jewelry producers.

The financial barriers to entering jewelry production are low. Becoming a manufacturer requires as little as CNY100,000 (US\$16,000) in start-up capital. Unregistered, small, and functionally specialized manufacturers that focus on either molding, plating, fitting, or embellishment dominate the production of jewelry for export to Africa. Suppliers coordinate the functionally disintegrated production. Unlike in high-end manufacturing, specialization among producers of fashion jewelry for African markets is a consequence of limited investment capital rather than of decisions to focus on core competences.

The manufacturers aspire to upgrade their production to serve markets with higher quality standards. "My factory is small and dirty. Come back in a few years - we will have a big and beautiful factory then," one manufacturer told me optimistically. She and her husband ran an unlicensed workshop producing low-grade products. The husband oversaw two dozen workers who were cutting, welding, and fitting the jewelry; she managed their sales office in a Guangzhou trading mall catering to African traders. However, breakneck competition made their production less and less profitable, and they were eventually forced to shut down. Other turnkey suppliers managed to pool enough orders to survive, but hired fewer workers on yearlong contracts and put in more labor themselves. Some large, licensed jewelry manufacturers joined the price-based competition for African customers after the 2008 financial crisis suppressed European and North American demand ${ }^{1}$.

\section{Suppliers in Guangzhou}

Guangdong's capital city Guangzhou has wholesale markets specializing in all types of consumer goods, from underwear to mobile phones. Xijiao market is the hub for wholesale of low-grade jewelry. While some wholesale offices are operated by Africans and Middle Easterners, most are run by Chinese. Their customers hail mainly from developing countries. The work of the businesspeople based in Xijiao, referred to as "suppliers" (gongyingshang), extends beyond wholesale: They coordinate manufacturing processes and provide the factories with designs. The Xijiao offices are used for display, assembly, repair, and packaging of jewelry. In an economy where family-managed businesses are the norm, only suppliers with kin who can oversee the production on a day-to-day basis may expand into manufacturing. Dwindling profits in manufacturing have reduced their interest in establishing

\footnotetext{
${ }^{1}$ For example, EU-28 imported 43,000 tons of "imitation jewelry" from China in 2007, and 41,900 tons of imitation jewelry in 2014, according to UN Comtrade (2015)
} 
factories. Suppliers act as brokers that keep the value chains together by putting fragmented producers in touch with a large number of small-scale traders. Unlike lead firms in GVCs, suppliers experience the same level of uncertainty and lack of control as other businesses along the value chain.

A jewelry supplier I recurrently will refer to in this article is Sara, a Chinese businessperson in her early twenties. Slender and often wearing a tracksuit, she appeared more like a factory worker than an executive. At the start of her career, Sara intended to expand into manufacturing, but scrapped these plans when profit levels dropped and her brother proved unfit as a manager. Instead, she worked with a select group of factories. She would sometimes carry out the final production step herself, assembling parts in her office in Xijiao, where Ghanaian jewelry traders went to find her on their trips to China.

Suppliers and manufacturers reenacted the tense relationship between risk and profit in the jewelry business through gambling. Gambling was associated with masculinity and capitalist wealth creation. In China, good fortune in gambling is believed to foreshadow business success (Basu 1991). When jewelry suppliers lost their capital at the betting tables, successful trading offices in Xijiao were closed overnight. The effects of such bankruptcies reverberated throughout the chain, leaving debts to manufacturers and material providers unpaid and partly paid jewelry orders unshipped.

\section{Ghanaian traders}

Ghanaian traders began importing non-precious jewelry directly from Mainland China in the late 1990s. The traders run wholesale stores in Accra. They visit China at intervals of a few weeks or several months, depending on how quickly their stocks sell out. While most Ghanaian jewelry traders are women, the wealthiest among them is an imposing man in his fifties. In the late 1990s, he was among the first Ghanaian traders to purchase goods in China.

In 2013, Baiyun Airport in Guangzhou recorded 530,000 entries by African passengers (Ping 2014). The number reveals how common it has become for African traders to source goods from Mainland China. Keeping abreast of fashion trends is one reason for traveling to Guangzhou rather than placing orders from home. The latest jewelry fashion, which used to be found in Paris, is now on display in Xijiao. Traders order from suppliers' collections of design samples, or bring their own models to have made-to-order. Less than a week may pass from when a new model is requisitioned to when production is completed.

Ghanaian traders import jewelry through two main channels. The goods can be sent by container to the Port of Tema in Ghana, or via Togo, an "entrepôt state" that maintains low 
customs barriers (Golub 2012). The jewelry is re-exported clandestinely from Togo to more protectionist countries, such as Ghana. Jewelry is sensitive to fashion changes, and most shipments therefore reach Accra by air. For their return trips from Guangzhou, Ghanaian traders can pay to check in up to twelve additional pieces of baggage, each weighing 32 kilograms. Such accompanied baggage is cheaper than regular air cargo, and crucial to the informal export of lightweight goods from China to Africa. Most traders paid clearing agents a flat rate of US\$50 per piece of luggage brought through customs.

To limit competition from Chinese importers, the Ghana Union of Traders Association (GUTA) has successfully lobbied to ban foreigners from bringing additional baggage when traveling into Ghanaian airports. Formal regulations thus facilitate informal economic activities for specific groups (Ghanaian traders) while disadvantaging others (foreign importers). The process illustrates that opportunities for "policy rents," rather than remaining outside the control of the firms (see Kaplinsky 1998), may be created in consultation with the benefiting parties.

\section{Retailers in Accra}

Retail in Africa is dominated by unbranded family-owned shops (KPMG 2014). Chinese jewelry reaches consumers through Ghanaian retailers, who are guaranteed exclusive rights to sell "in a market, petty trading, [or] hawking" by the Ghana Investment Promotion Act (Pollan 2006). For a short period, Chinese migrants managed retail shops fronted by Ghanaians, but those shops were replaced following a crackdown on illegal vending (Ho 2008).

Fashion jewelry is retailed in several ways. The most established retailers rent shops on ten-year contracts. They allow small-scale vendors to place tables with merchandise in front of their stores in return for practical help (Darkwah 2002). Such displays leave narrow passages at the sidewalks, on the edges of which other sellers put out racks and tables facing the road. The spaces are assigned to retailers according to customary laws enforced by the community of businesspeople. On the streets, hawkers with jewelry attached to aprons walk between cars stuck in constant traffic jams. Women with formal-sector jobs sell jewelry as a side business in their workplaces, schools, and homes, skillfully turning the symbolic capital invoked by their positions into commercial gains.

The categories of "genuine" and "fake" were employed as tropes for quality and trendiness in the jewelry trade. Much of the Chinese jewelry sold in Ghana was mounted on plastic boards marked "Made in France," but neither the wholesalers, retailers, nor customers 
pretended that this conveyed information about the site of production. Instead, confidence was invoked by the relationship between the seller and buyer. A case in point is that of an elegant woman with relatives in Europe, who had great success as a retailer. She studied and held an office job; her customers were fellow students and colleagues. The jewelry was made desirable by her persona in much the same way as brands may summon desire. "In Africa, attraction counts, in getting a job, in getting a husband, everything!" she explained. She saved the returns from the jewelry sales to travel to China and buy goods wholesale.

Retailers provided wholesalers with samples when new products hit the market. This practice conveyed information about styles and fashion up the value chain. Traders took the models to China and ordered replicas. When several traders copied the same jewelry model, the Ghanaian market was quickly flooded, prices plummeted, and losses were incurred.

\section{Symbolic exchanges and credit relations along the petty commodity chain}

Commercial relationships between vertically connected business partners were strengthened through symbolic exchanges. Gifts were sent downwards along the chain. Before Chinese New Year in January/February, manufacturers gifted fine foods and alcohol to suppliers who brought them business. Manufacturers Sara worked with handed her red envelopes with money (hongbao), a customary gift to unmarried business associates. The amount in the envelope reflected the size of her orders, and signaled the manufacturers' intention to strengthen their business relationship. Sara, in turn, occasionally bought gifts for the Ghanaian traders, often electronic products. Traders would sometimes reward retailers with a few extra pieces of jewelry.

Relationships can be broken off with the same informal instruments employed to build them. Before Chinese New Year in 2013, Sara received a hongbao with ten CNY100 bills from the owner of a materials factory. Her initial gratefulness turned to indignation when she learned that one of the bills was forged. She was certain that the manufacturer gave it to her to terminate their business relationship, an act that she regretted because of the high costs of finding a new manufacturer. Sara fixed the bill to her desk as a reminder of the treacherous nature of business relations. The transmission of risk along the value chain explains why the manufacturer chose to alienate Sara. While he appeared to trust her honest intentions, he might have doubted her ability to manage risk in her relations with traders. Sara worked with narrow profit margins and offered credit liberally because, as she put it, "jewelry is a volume business." 
The sequence of credit starts with Ghanaian traders, who ask suppliers to defer payments until the traders have resold some of the goods they order. The traders get goods on credit from suppliers, who in turn defer payments to manufacturers. At the very end of the credit chain, one finds the workers in informal jewelry factories, whose salaries are suspended until Chinese New Year. Credit relations tie business fortunes together: At any one time, all actors are owed money, and the effects of a default cascade throughout the chain. The chance of defaults is higher in international transactions because of currency risks, where a depreciation of the end-market currency impairs traders' ability to pay debts. Furthermore, debts are not backed by formal institutions that reduce the risk of opportunism. Debtorcreditor relationships are sticky: Debtors continue to buy from businesses that are willing to defer payments, and creditors fear losing their customers and receivables if they stop supplying them with goods.

\section{Establishing and maintaining credit relations}

Credit relations are strengthened through repeat and expanding transactions. A potential creditor must be convinced of the customer's intention and ability to repay. Suppliers evaluate traders' creditworthiness according to whom they are introduced by (usually other traders), the record of transactions they have established, and the frequency of their trips to China. Recurrent trips imply healthy capital circulation. Traders therefore see of their suppliers on every visit to China, regardless of whether they place new orders. During these visits, traders appraise suppliers' trustworthiness. A busy office indicates good fashion sense and reliability, which are important in a market where inferior quality is rampant.

The run-up to Chinese New Year tests the quality of business relationships along the jewelry chain. Workers must receive their accumulated earnings before they return home for the holiday. After Christmas - the high season for jewelry sales in much of Africa - suppliers call their customers in Ghana and urge them to repay debts promptly. Each time suppliers receive money, they reimburse manufacturers.

Events leading up to Chinese New Year in 2014 proved that the manufacturer who gave Sara a false banknote had reason to be worried. Sara struggled to recover her money. "I make money, but I don't see money," she complained, as the profit she calculated on her sales failed to reach her pocket because of outstanding debts. For the first time in her career, she opened a spreadsheet and made an overview of the money owed her. The debts amounted to CNY700,000 (US\$113,000). She pleaded with her customers to repay. Some traders sent a few thousand dollars, marginally reducing arrears. Sara withdrew CNY40,000 on two credit 
cards, and divided the paltry amount between the manufacturers she worked with. The factory owners were forced to use their family savings to pay workers' salaries. Though displeased, all but one continued to do business with Sara after the holiday.

The business model in the jewelry chain necessitates high-risk transactions. Strong cultural value is placed on risk-taking on the Chinese end of the chain, as illustrated by the account one jewelry supplier gave of his business expansion. He kept an office in a section of Xijiao nicknamed "the Golden Area," known for high sales volumes to African and Middle Eastern customers, but also frequent bankruptcies by suppliers who failed to meet short-term financial commitments. Aware of the Golden Area's popularity, the owners of Xijiao market charged exorbitant rents there. Golden Area offices could be maintained only through large cash flows. Thus, inaction was perceived as more foolish than were daring exploits, such as liberally extending credit to traders. The above-mentioned supplier rented an adjacent office in addition to his original one in the Golden Area, raising his total rent to CNY40,000 per month. He recounted with satisfaction that he proved wrong the people who warned him against expanding. By renting an ostentatious space, he had invoked the confidence of more traders, and orders increased immediately.

\section{Recovering debts}

Banks turn the morality of repayment into a matter of impersonal arithmetic that allows them to put indebted families out of their homes (Graeber 2011). Along petty commodity chains, by contrast, debt is not impersonalized. The means for collecting debts are situationally determined and guided by collective moral norms. Suppliers recognized that traders faced economic risks, product risks, and regulatory risks: Exchange rates fluctuate, goods are seized in customs, jewelry breaks before reaching the market, products suddenly go out of fashion, and theft and fires cause setbacks. If traders defaulted because of events beyond their control, suppliers could forgive debts and continue to give them goods on credit. Face-to-face interaction with debtors was crucial to assess trustworthiness in these cases. Chinese suppliers therefore occasionally traveled to Africa to collect money and evaluate traders' situations.

Sara's first trip outside China was to Accra, where she wanted to collect money from traders. Fatou, one of the debtors, blamed a slow market when Sara approached her to recover US\$15,000. Sara discussed the issue with another customer, Mariam, who had introduced her to Fatou a year earlier. They concluded that the debt was legitimate: Fatou had sold most of the jewelry Sara had supplied, but spent the money on building a house. "It's not right for her to enjoy the money when you are stressed," Mariam said. She had witnessed Sara break down 
and cry because of her mounting debts to manufacturers. Sara asked Mariam to explain her predicament to Fatou. "I cannot talk your feelings for you!" Mariam said, and encouraged Sara to show Fatou her desperation to give the demand for repayment greater moral weight. Another Ghanaian acquaintance suggested instead that Sara prepare a debt letter for Fatou to sign. Sara rejected this option, fearing that a written statement signified a lack of trust, thus reducing the debtor's commitment to pay. Overt negotiation of terms and binding agreements - measures introduced in formal business networks for the very reason that they reduce risk in transactions - would ultimately diminish interpersonal confidence.

Dishonesty, too, could be forgiven in relationships in the jewelry economy. Some deception was expected; whether it was tolerated depended on the extent and the situation. For example, manufacturers consistently gave Sara slightly fewer jewelry pieces than they charged for. She confronted them only if she found the discrepancy unfairly large. Similarly, Ghanaian wholesalers tacitly accepted that Chinese suppliers copied their designs when they placed small orders. Traders were more tolerant of copying when suppliers introduced time lags before reproducing their models or refrained from selling to direct competitors.

Chinese suppliers needed informal connections in Ghana to access the country's legal structures. Sara did not have such connections. A colleague of hers, by contrast, used the Ghanaian state apparatus to recover money. He solicited the help of a well-connected business partner in Accra to recover a US\$20,000 debt from a Ghanaian trader. They called an unofficial meeting with a bureaucrat from the Criminal Investigation Department (CID), a family friend of the Ghanaian trader. Upon checking the debt letter, the CID official offered to send off-duty police officers to the debtor to force her to pay. The official charged US\$550, some of which he spent on paying the police officers. The arrangement illustrates the blurred distinction between formal and informal institutions. On another occasion, the well-connected Ghanaian businessman advised against collecting a debt by means of the police, as this reaction would have been perceived as excessive under the circumstances and would have given the supplier a bad reputation. In the jewelry business, legal action to collect debts did not necessarily have more legitimacy than violence did, and in some situations, neither option was available.

The threat of violence loomed when suppliers did not meet their obligations to manufacturers. A group of men was sent to intimidate Sara when she failed to reimburse a manufacturer before Chinese New Year. She eventually managed to pay, but their business relationship was irreparable. The incident made Sara determined not to be perceived as soft by people owing her money. She contacted a Chinese debt collecting agency to recover 
CNY100,000 (US\$16,000) owed by a wealthy Nigerian trader. The debt collectors traveled regularly to Nigeria, where they worked with local partners. They charged 40 percent commission on any amounts retrieved, and were ready to assist only upon receiving proof of the debt. The collection agency had no qualms about using violence and working with vigilante groups, but they would lose legitimacy if they engaged in extortion when a debt was not genuine. The incidents recounted above illustrate that for means of enforcement to be effective and to avoid causing reputational damage, they must be grounded in common moral principles.

\section{Beholden value chains}

GVC governance classifications have not been informed by research on petty commodity economies, and fail to capture the governance characteristics of petty commodity chains. For example, the typology developed by Gereffi et al (2005), which characterize value chain governance as market-based, modular, relational, captive, or hierarchical, provides no governance classification that fits petty commodity chains. Based on the review of the literature on informal transborder trade and the fieldwork data, I propose beholden value chains as a governance classification. Unlike the five governance modes outlined by Gereffi et al, this is an empirically rather than analytically derived category.

The term "beholden" emphasizes the social and durable nature of relationships between vertically connected actors. The actors are indebted, both financially and socially: They owe money to businesses further up the chain, and they owe their appreciation to the businesses further down the chain for bringing them orders. Conversely, all business actors find other actors beholden to them at any one time. If they break off these relationships, the possibilities for recovering outstanding assets are reduced. Business success is achieved through forging relationships of mutual obligations and managing these competently. However, there is always an element of risk because actors are affected by relations further along the value chain.

The stability of business relations in petty commodity chains is first and foremost promoted by credit relations. The organization of the chains does not prescribe a clean handoff between trading partners. Downstream partners owe money for the goods they have received, and their commitment to repay decrease if their business partner declines to send more goods on credit. Suppliers are held accountable for the merchandise after the goods reach the retail market: Traders use defective or obsolete goods as an argument for debt concession from suppliers. Legal action and threats of violence are means of last resort to 
recover debts, as these measures destroy the possibilities for future transactions and may damage one's reputation.

The mutual reliance between vertically related actors in beholden value chains suggests that power asymmetry is not a necessary condition for relations of dependency to subsist. Value chains can be tightly held together without lead firms. Which actor had the upper hand in the China-Ghana jewelry trade was situationally determined and subject to change. Actors continuously assessed the risks associated with sustaining specific business relationships, and strengthened, maintained, or severed relations through symbolic exchanges. Power in beholden value chains is a temporary result of ongoing work to create and maintain relationships that enable value capture.

The strength of the GVC framework is to highlight how specific business relationships are affected by the organization of the full value chain. Credit relations transmit risks across product stages and geographic space. The relationship between two businesses in immediate contact with each other must therefore be understood with reference to extended stretches of the value chain. In petty commodity chains, the effects of debt default reverberate directly upstream: When a Ghanaian trader fails to repay her debt to a jewelry supplier, the ultimate consequence may be that Chinese workers who manufactured the jewelry are deprived of their hard-earned salaries.

\section{Conclusion}

The business relationships along the China-Ghana jewelry chain are trust-based and adaptable, but also frail and potentially violent. Personalized relations along the chain are formed out of necessity rather than affinity; there are no formal institutions to substitute for interpersonal trust. A strong sense of vulnerability prevails among manufacturers, suppliers, and traders, and is increased by the lack of enforceable quality standards, and volatile macro-economic environments. This article has proposed that the governance of petty commodity chains can be captured by the concept of beholden value chains. This concept combines insights from GVC/GPN studies and the ethnographic literature on transborder trade. Informal credit practices are well documented in the latter tradition, while GVC/GPN researchers turned their attention to the role of credit mainly after the 2008 financial crisis.

The growing urgency of understanding economic transactions within the global South is recognized by economic geographers, who nevertheless have been slow to engage with research on South-South transactions from other disciplines. The empirical material presented in this article supports findings from the emerging scholarship on GVCs in developing- 
country contexts, which asserts that the pressures resulting from economic globalization are no less detrimental within the context of South-South trade. Creating and maintaining relationships that enable value capture can be more messy and unpredictable than research on GVCs/GPNs in the global North suggests. For GVC/GPN approaches to remain effective tools for studying the global economy, their foundation must continue to expand beyond the formal sector and developed country end markets.

Given what is known about the structure of petty commodity chains, is there reason to be sanguine about their developmental potential? Petty capitalism has provided means for people to make a living in volatile times and in the absence of other opportunities. Informal commercial importers have effectively addressed supply shortages and provided people with affordable goods. Some of these importers and small-scale informal manufacturers have moved into the middle class. Factory workers and street-side retailers manage to eek out a living in the informal economy. However, petty commodity chains provide no panacea for economic woes. At best, they can offer stopgap measures in periods of transition or be a point of entry into more sustainable economic activities. At worst, petty commodity production and trade undermine health and safety standards, contribute to environmental degradation, reinforce state corruption, threaten consumer safety, and prevent industrial development in the end markets. Future research on petty commodity chains should elucidate not only their configuration and governance, but also their wider consequences for economic development.

\section{References}

Alvarez, R. R. 2005. Mangos, chiles, and truckers: the business of transnationalism, Minneapolis, University of Minnesota Press.

Axelsson, L. \& Sylvanus, N. 2010. Navigating Chinese textile networks: women traders in Accra and Lomé. In: Cheru, F. \& Obi, C. (eds.) The rise of China and India in Africa. London: Zed Books.

Bair, J. \& Werner, M. 2011. The place of disarticulations: global commodity production in La Laguna, Mexico. Environment and Planning A, 43, 998-1015.

Barrientos, S. W. 2013. 'Labour Chains': Analysing the Role of Labour Contractors in Global Production Networks. The Journal of Development Studies, 49, 1058-1071.

Basu, E. O. 1991. Profit, Loss, and Fate: The Entrepreneurial Ethic and the Practice of Gambling in an Overseas Chinese Community. Modern China, 17, 227-259.

Brautigam, D. 2016. Data: Chinese Loans and Aid to Africa [Online]. Washington, DC. Available: http://www.sais-cari.org/data-chinese-loans-and-aid-to-africa. Accessed 16.06.2016.

Brooks, A. 2012. Networks of power and corruption: the trade of Japanese used cars to Mozambique. The Geographical Journal, 178, 80-92.

Brooks, A. 2015. Clothing Poverty: The Hidden World of Fast Fashion and Second-Hand Clothes, London, Zed Books. 
Burawoy, M. \& Verdery, K. (eds.) 1999. Uncertain transition: Ethnographies of change in the postsocialist world, Lanham, Md.: Rowman \& Littlefield.

Cattaneo, O., Gereffi, G. \& Staritz, C. 2010. Global value chains in a post-crisis world: Resilience, consolodation, and shifting end markets. In: Cattaneo, O., Gereffi, G. \& Staritz, C. (eds.) Global value chains in a post-crisis world. Washington DC: The World Bank.

Coe, N. M. \& Yeung, H. W. C. 2015. Global Production Networks: Theorizing Economic Development in an Interconnected World, Oxford, Oxford University Press.

Darkwah, A. 2002. Going global: Ghanaian female transnational traders in an era of globalization (PhD Dissertation), Madison, University of Wisconsin-Madison.

Ebin, V. 1993. Les commerçants mourides à Marseille et à New York. In: Grégoire, E. \& Labazée, P. (eds.) Grands commerçants d'Afrique de l'Ouest: logiques et pratiques d'un groupe d'hommes d'affaires contemporains. Paris: Éditions Karthala.

Economic Geography 2011. Editorial: Emerging Themes in Economic Geography: Outcomes of the Economic Geography 2010 Workshop. Economic Geography, 87, 111-126.

Escaith, H. \& Gonguet, F. 2009. International trade and real transmission channels of financial shocks in globalized production networks, Geneva, Word Trade Organization.

Galletti, R., Baldwin, K. \& Dina, I. 1956. Nigerian cocoa farmers, Oxford, Oxford University Press.

Gates, H. 1996. China's Motor: A Thousand Years of Petty Capitalism, Ithaca, Cornell University Press.

Gereffi, G. 1994. The Organization of Buyer-Driven Global Commodity Chains: How US Retailers Shape Overseas Production Networks. In: Gereffi, G. \& Korzeniewicz, M. (eds.) Commodity chains and global capitalism. Westport Conn.: Praeger Publishers.

Gereffi, G. 2014. Global value chains in a post-Washington Consensus world. Review of International Political Economy, 21, 9-37.

Gereffi, G., Humphrey, J. \& Sturgeon, T. 2005. The governance of global value chains. Review of International Political Economy, 12, 78-104.

Gibbon, P. \& Ponte, S. 2005. Trading down: Africa, value chains, and the global economy, Philadelphia, Temple University Press.

Golub, S. S. 2012. Entrepôt Trade and Smuggling in West Africa: Benin, Togo and Nigeria. The World Economy, 35, 1139-1161.

Graeber, D. 2011. Debt: The First 5,000 Years, Brooklyn, NY, Melville House.

Guarín, A. \& Knorringa, P. 2013. New Middle-Class Consumers in Rising Powers: Responsible Consumption and Private Standards. Oxford Development Studies, 42, 151-171.

Ho, C. G.-Y. 2008. The "Doing" and "Undoing" of Community: Chinese Networks in Ghana. Journal of Current Chinese Affairs, 37, 46-77.

Horner, R. 2013. Strategic decoupling, recoupling and global production networks: India's pharmaceutical industry. Journal of Economic Geography, Online first, doi: 10.1093/jeg/lbt022.

Horner, R. 2015. A New Economic Geography of Trade and Development? Governing South-South Trade, Value Chains and Production Networks. Territory, Politics, Governance, 1-21.

Hughes, A., Mcewan, C. \& Bek, D. 2015. Postcolonial perspectives on global production networks: insights from Flower Valley in South Africa. Environment and Planning A, 47, 249-266.

Humphrey, J. \& Schmitz, H. 2002. How does insertion in global value chains affect upgrading in industrial clusters? Regional Studies, 36, 1017-1027. 
Kaplinsky, R. 1998. Globalisation, Industrialisation and Sustainable Growth: The pursuit of the Nth rent, Brighton, Institute for Development Studies.

Kaplinsky, R., Terheggen, A. \& Tijaja, J. 2011. China as a Final Market: The Gabon Timber and Thai Cassava Value Chains. World Development, 39, 1177-1190.

Konstantinov, Y., Kressel, G. M. \& Thuen, T. 1998. Outclassed by former outcasts: Petty trading in Varna. American Ethnologist, 25, 729-745.

Kpmg. 2014. The African Consumer and Retail. Sector Report [Online]. Available: http://www.kpmg.com/Africa/en/IssuesAndInsights/Articles-Publications/GeneralIndustries-

Publications/Documents/African\%20Consumer\%20and\%20Retail\%20Report.pdf Accessed 15.09.2015.

Liao, H. F. \& Chan, R. C. 2011. Industrial relocation of Hong Kong manufacturing firms: towards an expanding industrial space beyond the Pearl river delta. GeoJournal, 76, 623-639.

Lyons, M., Brown, A. \& Li, Z. 2013. The China-Africa Value Chain: Can Africa's SmallScale Entrepreneurs Engage Successfully in Global Trade? . African Studies Review, $56,77-100$.

Macgaffey, J. \& Bazenguissa-Ganga, R. 2000. Congo-Paris: Transnational traders on the margins of the law, Oxford, James Currey.

Marcus, G. E. 1995. Ethnography in/of the World System: The Emergence of Multi-Sited Ethnography. Annual Review of Anthropology, 24, 95-117.

Marx, K. 1991. Capital, London, Penguin Books.

Meagher, K. 2003. A back door to globalisation? Structural adjustment, globalisation \& transborder trade in West Africa. Review of African Political Economy, 30, 57-75.

Mezzadri, A. 2010. Globalisation, informalisation and the state in the Indian garment industry. International Review of Sociology, 20, 491-511.

Milberg, W. \& Winkler, D. 2010. Trade Crisis and Recovery. Restructuring of Global Value Chains. Policy Research Working Paper. Washington DC: The World Bank.

Morawska, E. 1999. The malleable homo sovieticus: transnational entrepreneurs in postcommunist East Central Europe. Communist and Post-Communist Studies, 32, 359378.

Murphy, J. T. 2007. The challenge of upgrading in African industries: Socio-spatial factors and the urban environment in Mwanza, Tanzania. World Development, 35, 1754-1778.

Murphy, J. T. 2008. Economic Geographies of the Global South: Missed Opportunities and Promising Intersections with Development Studies. Geography Compass, 2, 851-873.

Murphy, J. T. \& Schindler, S. 2011. Globalizing development in Bolivia? Alternative networks and value-capture challenges in the wood products industry. Journal of Economic Geography, 11, 61-85.

Nadvi, K. 2004. Globalisation and Poverty: How can global value chain research inform the policy debate? IDS bulletin, 35, 20-30.

Nadvi, K. 2014. "Rising Powers" and Labour and Environmental Standards. Oxford Development Studies, 42, 137-150.

Peberdy, S. A. 2000. Border crossings: Small enterpreneurs and cross-border trade between South Africa and Mozambique. Tijdschrift voor economische en sociale geografie, 91, 361-378.

Phillips, N. 2011. Informality, global production networks and the dynamics of 'adverse incorporation'. Global Networks, 11, 380-397.

Ping, Q. 2014. 广州市副市长: 说广州有几十万非洲人是误解 (The vice mayor of Guangzhou says hundres of thousands of Africans is a misunderstanding). Southern Metropolis Daily. Guangzhou: The Nanfang Group. 
Pollan, T. 2006. Legal Framework for the Admission of FDI, The Hague, Eleven International Publishing.

Pollard, J., Mcewan, C. \& Hughes, A. 2011. Introduction: postcolonial economies. In: Pollard, J., Mcewan, C. \& Hughes, A. (eds.) Postcolonial economies. London: Zed Books.

Prag, E. 2013. Mama Benz in Trouble: Networks, the State, and Fashion Wars in the Beninese Textile Market. African Studies Review, 56, 101-121.

Rubbers, B. 2009. 'We, the Congolese, we cannot trust each other'. Trust, norms and relations among traders in Katanga, Democratic Republic of Congo. The British Journal of Sociology, 60, 623-642.

Schneider, F., Buehn, A. \& Montenegro, C. E. 2010. New Estimates for the Shadow Economies all over the World. International Economic Journal, 24, 443-461.

Smart, A. \& Smart, J. 2006. Introduction. In: Smart, A. \& Smart, J. (eds.) Petty Capitalists And Globalization: Flexibility, Entrepreneurship, And Economic Development. New York: State University of New York Press.

Smart, J. \& Smart, A. 1991. Personal Relations and Divergent Economies: a Case Study of Hong Kong Investment in South China. International Journal of Urban and Regional Research, 15, 216-233.

Sturgeon, T. 2002. Modular production networks: a new American model of industrial organization. Industrial and Corporate Change, 11, 451-496.

Thomsen, L. 2007. Accessing global value chains? The role of business-state relations in the private clothing industry in Vietnam. Journal of Economic Geography, 7, 409-430.

Un Comtrade. 2015. International Trade Statistics database [Online]. Available: www.comtrade.un.org.

Wei, Y. D., Li, W. \& Wang, C. 2007. Restructuring Industrial Districts, Scaling Up Regional Development: A Study of the Wenzhou Model, China. Economic Geography, 83, 421444.

Yeung, H. W.-C. 2004. Chinese capitalism in a global era: towards hybrid capitalism, London, Routledge.

Yükseker, D. 2007. Shuttling goods, weaving consumer tastes: Informal trade between Turkey and Russia. International Journal of Urban and Regional Research, 31, 60-72.

Zein-Elabdin, E. 2011. Postcolonial theory and economics: Orthodox and heterodox. In: Mcewan, C., Hughes, A. \& Pollard, J. (eds.) Postcolonial economies. London: Zed Books. 